Mycologia

\title{
Determination of amatoxins and phallotoxins in Amanita phalloides mushrooms from northeastern Portugal by HPLC-DAD-MS
}

Juliana Garcia, Ana Oliveira, Paula Guedes de Pinho, Victor Freitas, Alexandra Carvalho, Paula Baptista, Eric Pereira, Maria de Lourdes Bastos \& Félix Carvalho

To cite this article: Juliana Garcia, Ana Oliveira, Paula Guedes de Pinho, Victor Freitas, Alexandra Carvalho, Paula Baptista, Eric Pereira, Maria de Lourdes Bastos \& Félix Carvalho (2015)

Determination of amatoxins and phallotoxins in Amanita phalloides mushrooms from northeastern Portugal by HPLC-DAD-MS, Mycologia, 107:4, 679-687, DOI: 10.3852/14-253

To link to this article: https://doi.org/10.3852/14-253

巴nublished online: 20 Jan 2017.

Submit your article to this journal $\sqsubset$

Џll Article views: 69

Q View related articles $\sqsubset$

View Crossmark data ¿ 
Mycologia, 107(4), 2015, pp. 679-687. DOI: 10.3852/14-253

(C) 2015 by The Mycological Society of America, Lawrence, KS 66044-8897

\section{Determination of amatoxins and phallotoxins in Amanita phalloides mushrooms from northeastern Portugal by HPLC-DAD-MS}

Juliana Garcia ${ }^{1}$

Ana Oliveira

Division of Medical Sciences $\mathcal{E}$ Graduate Entry Medicine, School of Medicine, Faculty of Medicine $\mathcal{E}^{\circ}$ Health Sciences, University of Nottingham, Royal Derby Hospital Centre, Derby, NG7 2UH, United Kingdom

Paula Guedes de Pinho UCBIO-REQUIMTE/Laboratory of Toxicology, Department of Biological Sciences, Faculty of Pharmacy, University of Porto, Rua Jorge Viterbo Ferreira 228, 4050-313 Porto, Portugal

Victor Freitas

Centro de Investigação em Química, Departamento de Química, Faculdade de Ciências, Universidade do Porto, Porto, Portugal

Alexandra Carvalho

Institute of Computational Chemistry and Department of Chemistry, University of Girona, 17071 Girona, Spain

Paula Baptista

Eric Pereira CIMO/School of Agriculture, Polytechnic Institute of Braganca, Campus de Santa Apolónia, Apartado 1172, 5301-854 Bragança, Portugal

Maria de Lourdes Bastos

Félix Carvalho ${ }^{1}$

UCBIO-REQUIMTE/Laboratory of Toxicology, Department of Biological Sciences, Faculty of Pharmacy, University of Porto, Rua Jorge Viterbo Ferreira 228, 4050-313 Porto, Portugal

\begin{abstract}
Amanita phalloides is a toxic mushroom responsible for the majority of deaths occurring after mushrooms ingestion, mainly due to amatoxins. In the present study the contents and distribution of the major amatoxins and phallotoxins in different tissues of A. phalloides from two different sites of Portugal were analyzed by liquid chromatography (LC) coupled to diode array (DAD) and mass spectrometry (MS) detection. The main toxins were separated by LC and its chemical structures confirmed by MS. $\alpha$-Amanitin contents in caps, stipe and volva tissues were quantified by RP-HPLC. The results show that caps have the highest content of amatoxins, whereas the volva was richest in phallotoxins. Moreover variability in the

Submitted 26 Sep 2014; accepted for publication 23 Mar 2015.

${ }^{1}$ Corresponding author. E-mail: jugarcia@hotmail.com; felixdc@ ff.up.
\end{abstract}

toxins composition from different geographic sites was also observed. This study provides for the first time the content of toxins in $A$. phalloides from Portugal.

Key words: $\alpha$-amanitin, Amanita phalloides, mass spectrometry, reversed-phase high performance liquid chromatography, toxins

\section{INTRODUCTION}

Amanita phalloides (death cap) is one of the most toxic mushrooms worldwide. Fatalities due to A. phalloides poisoning account to about $90 \%$ of deaths occurring after ingestion of mushrooms (Karlson-Stiber and Persson 2003). This mushroom species grows in symbiosis with trees, such as beech or oak in Europe and America. Amanita phalloides is characterized by greenish yellow cap, darker in the center and faintly streaked radially (FIG. 1). The stipe is smooth and white, and it has a distinct ring. The base of the stipe is enclosed in a volva, which is a distinctive and morphological diagnostic feature (Bonnet and Basson 2002). Poisoning from the consumption of this mushroom usually occurs as a result of confusion of A. phalloides with edible mushroom species, such as Amanita fulva, Agaricus spp., Macrolepiota procera and Tricholoma portentosum (Barceloux 2008). Cooking, freezing and drying do not eliminate the toxicity of $A$. phalloides (Vetter 1998).

This species contains two main groups of toxins, amatoxins and phallotoxins. The amatoxins group is composed by $\alpha$-amanitin (AA), $\beta$-amanitin (BA), $\gamma$-amanitin (GA), $\varepsilon$-amanitin, amaninamide, amanin, amanullin, amanullic acid and proamanullin (FIG. 2). The phallotoxin group consists of phalloidin (PHD), phalloin, prophallin, phallisin (PHS), phallacin, phallacidin (PCD) and phallisacin (FIG. 3) (Vetter 1998). Amatoxins are the main toxins responsible for the toxicity and the human fatalities following intoxication with $A$. phalloides. The mechanism of action of amatoxins is not completely understood but it is known that the main target of AA is hepatic RNA polymerase II enzyme. Following uptake by organic anion-transporting octapeptide (OATP) located in the sinusoidal membrane of hepatocytes, AA inhibits RNA polymerase II, reducing the mRNA synthesis and consequently provoking a decrease of protein contents and ultimately liver cell death (Mas 2005). The mechanisms of toxicity of AA has been studied by our group, and we have focused our efforts 


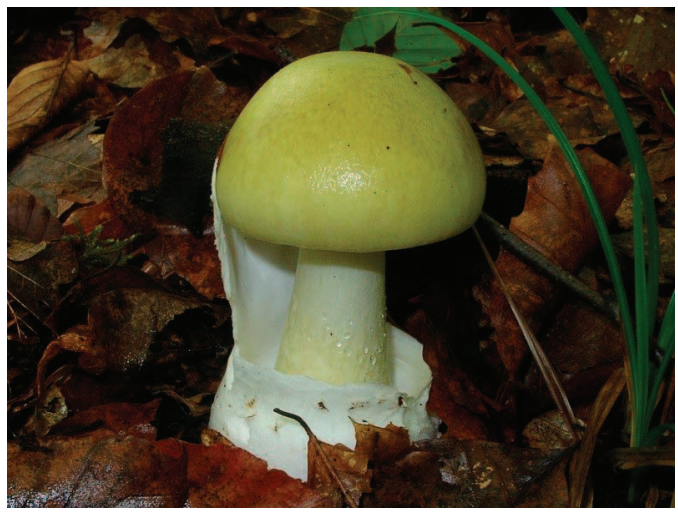

FIG. 1. Basidiocarp of Amanita phalloides (death cap) from Vinhais, Portugal.

on understanding the molecular mechanism of RNA polymerase II inhibition (Garcia et al. 2014).

Several methods for isolation and analysis of amatoxins and phalotoxins have been published, the reversed-phase high performance liquid chromatography (RP-HPLC) being the most common method (Enjalbert et al. 1996, Enjalbert et al. 1999, Enjalbert et al. 1993, Enjalbert et al. 1992, Enjalbert et al. 2002, Hu et al. 2012). Enjalbert et al. have been analyzed the content of main toxins in A. phalloides showing that the amount of toxins depends on climate, topography and soil characteristics (Enjalbert et al. 1996, Enjalbert et al. 1999). In addition significant differences in amounts of toxins in different tissues of the fruiting body and in different growth phases also have been noted (Enjalbert et al. 1996). The quantification of $A$. phalloides toxins in different part of the globe is important to get the greatest information possible, to ascertain its relative morbidity and lethal potential. To our knowledge, there is no study on the toxin content of A. phalloides from Portugal.

In this work A. phalloides collected in north of Portugal were investigated for amatoxins and phallotoxins with liquid chromatography-diode array and mass spectrometry detection (LC-DAD-MS). AA was quantified from caps, stipe and volva by RP-HPLC and DAD.

\section{MATERIALS AND METHODS}

Chemicals. $-\alpha$-amanitin ( $>90 \%$ pure) was purchased from Sigma-Aldrich. Acetonitrile (hypergrade) was brought from Fisher Chemicals. Water was purified with a Milli-Q Plus ultrapure water purification system (Millipore, Bedford, Massachusetts).

Description of the study area.-Considering the geographic differences, northeastern Portugal province of Trás-osMontes can be grouped into two areas: the "terra fria", (cold land) in the northern area, with higher altitudes, and the "terra quente" (hot lands) located in the southern areas, marked by the valleys of the Douro River (Dias et al. 2012). These two areas have significant climatic differences. Cold land is characterized by prolonged winter and a brief hot summer with annual mean precipitation of $800 \mathrm{~mm}$ and mean temperature of 12.5 C. On the other hand, hot land has a warm and dry summer and mild winter with annual mean temperature of $14.0 \mathrm{C}$ and annual precipitation of $1200 \mathrm{~mm}$ (Evelpidou et al. 2010). The Vinhais region is in Cold Land, whereas Mogadouro is in the Hot Land. The varieties of topographic and climatic conditions have a great impact on the type of soil. In fact, according to the Soil Map of Northeast Portugal, 1:100 000 (Agroconcultores and Coba 1991), which follows the FAO system of classification (FAO/UNESCO 1987), leptosols are largely dominant in Mogadouro, whereas cambisols are the most representative soils of Vinhais.

Amanita phalloides and soil sampling.-Amanita phalloides fruiting body were collected in the Trás-os-Montes region in Oct, Nov 2012 from two sites named Vinhais and Mogadouro. The set consisted of 25 mature fruiting body. Mushrooms were identified with morphological features and appropriate keys and monographs including Courtecuisse and Courtecuisse \& Duhem (Courtecuisse 1999, Courtecuisse and Duhem 2005). Immediately after harvesting the mushrooms were dried for $3 \mathrm{~d}$ at $60 \mathrm{C}$. Each specimen was divided into three parts, namely the cap, stipe and volva. Representative voucher specimens (No. 447) were deposited at the herbarium of School of Agriculture of the Polytechnic Institute of Bragança, Portugal.

Soils samples from sites in Vinhais and Mogadorouro regions were collected and represent different soil types (leptosol and cambisol). Bulk soil samples (six replicates per soil, $0.5 \mathrm{~kg}$ per replicate) were collected in plastic bags and thoroughly homogenized before further processing. The soil pH was determined according to ISO 10390:2005 method. The solid samples (weight $10 \mathrm{~g}$ ) were treated with $50 \mathrm{~mL} 1 \mathrm{M} \mathrm{KCl}$, with stirring for $30 \mathrm{~min}$. After $1 \mathrm{~h}$ the $\mathrm{pH}$ for the each sample was measured at room temperature.

Extraction of toxins. - Several methods have been described in the past few years for the extration of phallotoxins from fungi (Enjalbert et al. 1992, Enjalbert et al. 1996, Kaya et al. 2013). These methods are often laborious and time consuming. This is usually because most of the available protocols include multiple steps of solid/liquid extraction followed by incubation overnight. In addition to being lengthy, these methods also involve large amount of samples $(2 \mathrm{~g})$, which is a limitation when the amount of mushrooms available is scarce. Thus we used a simpler but fully effective extraction method described by Jansson et al. (2012) with minor modifications. Briefly, cap, stipe or volva were ground to a powder in a mortar, after $0.5 \mathrm{~g}$ (dry weight) of were extracted during $1 \mathrm{~h}$ with $1 \mathrm{~mL}$ milli-Q water and $6 \mathrm{~mL}$ acetonitrile. After centrifugation at 3000 rpm for $30 \mathrm{~min}$, the supernatant was used for LC-MS analysis. The same supernatant was used for AA quantification by reversed-phase RP-HPLC.

Identification of $\mathrm{A}$. phalloides toxins by liquid chromatography-diode array and mass spectrometry detection.-A Finnigan 


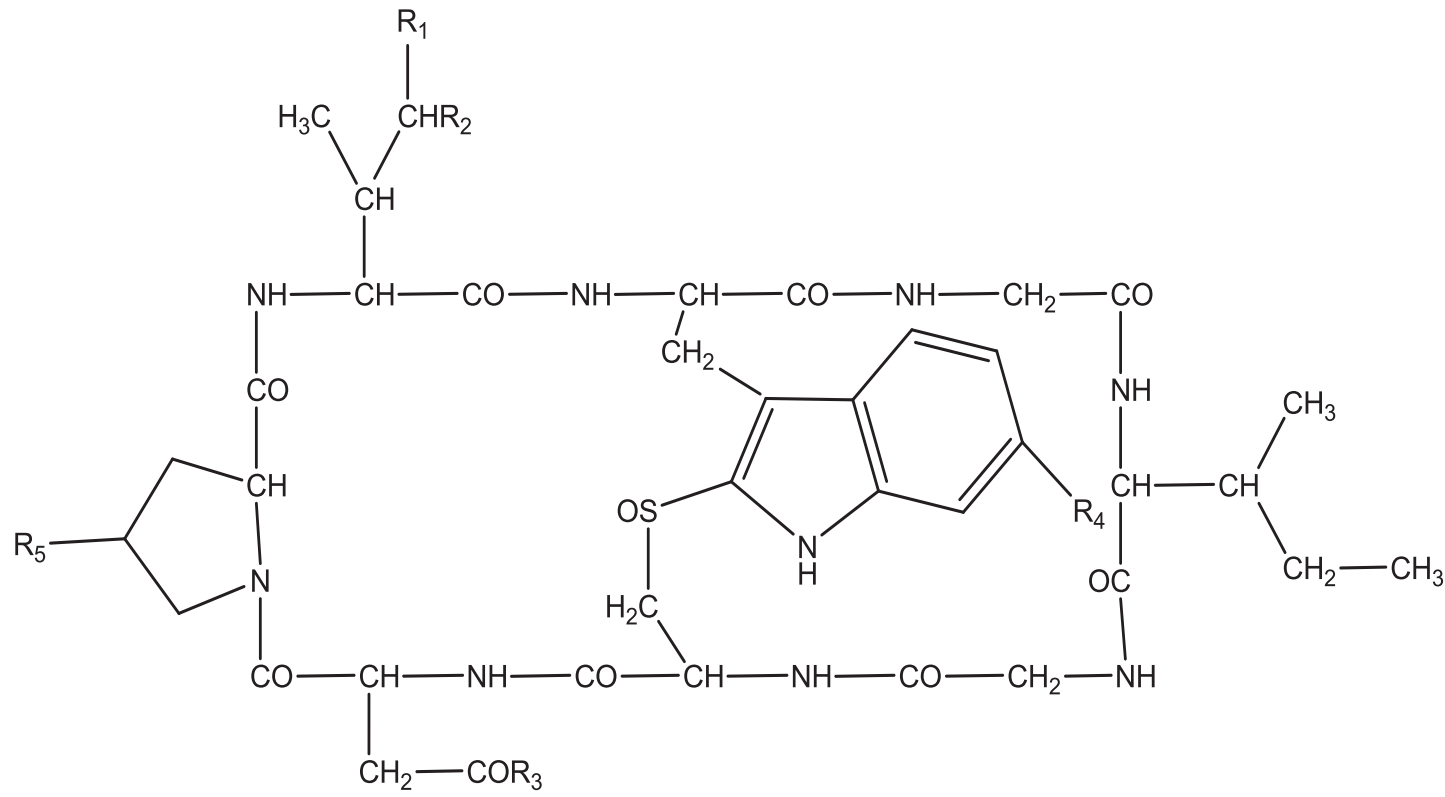

\begin{tabular}{|c|c|c|c|c|c|}
\hline & R1 & $\mathbf{R 2}$ & R3 & R4 & R5 \\
\hline$\alpha$-amanitin & $\mathrm{CH}_{2} \mathrm{OH}$ & $\mathrm{OH}$ & $\mathrm{NH}_{2}$ & $\mathrm{OH}$ & $\mathrm{OH}$ \\
\hline$\beta$-amanitin & $\mathrm{CH}_{2} \mathrm{OH}$ & $\mathrm{OH}$ & $\mathrm{OH}$ & $\mathrm{OH}$ & $\mathrm{OH}$ \\
\hline$\gamma$-amanitin & $\mathrm{CH}_{3}$ & $\mathrm{OH}$ & $\mathrm{NH}_{2}$ & $\mathrm{OH}$ & $\mathrm{OH}$ \\
\hline$\varepsilon$-amanitin & $\mathrm{CH}_{3}$ & $\mathrm{OH}$ & $\mathrm{OH}$ & $\mathrm{OH}$ & $\mathrm{OH}$ \\
\hline Amanin & $\mathrm{CH}_{2} \mathrm{OH}$ & $\mathrm{OH}$ & $\mathrm{OH}$ & $\mathrm{H}$ & $\mathrm{OH}$ \\
\hline Amanin amide & $\mathrm{CH}_{2} \mathrm{OH}$ & $\mathrm{OH}$ & $\mathrm{NH}_{2}$ & $\mathrm{H}$ & $\mathrm{OH}$ \\
\hline Amanullin & $\mathrm{CH}_{3}$ & $\mathrm{H}$ & $\mathrm{NH}_{2}$ & $\mathrm{OH}$ & $\mathrm{OH}$ \\
\hline Amanullic acid & $\mathrm{CH}_{3}$ & $\mathrm{H}$ & $\mathrm{OH}$ & $\mathrm{OH}$ & $\mathrm{OH}$ \\
\hline Proamanullin & $\mathrm{CH}_{3}$ & $\mathrm{H}$ & $\mathrm{NH}_{2}$ & $\mathrm{OH}$ & $\mathrm{H}$ \\
\hline
\end{tabular}

FIG. 2. Chemical structure of amatoxins The backbone structure is the same in all amatoxins, and five variable groups determine the specific compound.

surveyor series LC, equipped with Lichrocart Purospher ${ }^{\circledR}$ Star reversed-phase column $(\mathrm{C} 18,150 \mathrm{~mm} \times 4.6 \mathrm{~mm} \times 5 \mu \mathrm{m})$ was used. The mobile phases flow rate was $0.5 \mathrm{~mL} \cdot \mathrm{min}^{-1}$ and consisted of $0.02 \mathrm{M}$ aqueous ammonium acetate adjusted to pH 5.0 with glacial acetic acid and acetonitrile (Zhao et al.
2006). The gradient profile was: $0 \rightarrow 15 \mathrm{~min}, 0 \% \rightarrow 2.3 \%$ solvent $\mathrm{B} ; 15 \rightarrow 35 \mathrm{~min}, 2.3 \% \rightarrow 37.9 \%$ solvent $\mathrm{B} ; 35 \rightarrow 40$, $37.9 \% \rightarrow 37.9 \%$ solvent $\mathrm{B} ; 40 \rightarrow 45 \mathrm{~min}, 37.9 \% \rightarrow 100 \%$ solvent $\mathrm{B} ; 45 \rightarrow 50 \mathrm{~min}, 100 \% \rightarrow 100 \%$ solvent $\mathrm{B} ; 50 \rightarrow 55 \mathrm{~min}$, $100 \% \rightarrow 0 \%$ solvent $\mathrm{B} ; 55 \rightarrow 65,0 \% \rightarrow 0 \%$ solvent. The sample 
injection volume was $20 \mu \mathrm{L}$. The chromatographic column was stabilized with the initial conditions for $10 \mathrm{~min}$. Doubleonline detection was done by a DAD and MS detectors. The MS detector was a Finnigan LCQ DECA XP MAX (Finnigan Corp., San Jose, California) quadrupole ion trap equipped with atmospheric pressure ionization source, using ESI. The vaporizer and the capillary voltages were $5 \mathrm{kV}$ and $4 \mathrm{~V}$ respectively. The capillary temperature was set at $325 \mathrm{C}$. Nitrogen was used as both sheath and auxiliary gas at flow rates of 90 and 35 respectively (in arbitrary units).

Quantification of amatoxins by high-pressure liquid chromatography with diode array detection.-Analyses were performed using a RP-HPLC method (Enjalbert et al. 1992). An HPLC system (Waters model 2690) equipped with a photodiode array detector (Waters model 996) and C-18 column from Waters $(\mathrm{C} 18,150 \mathrm{~mm} \times 4.6 \mathrm{~mm} \times 5 \mu \mathrm{m})$ was used. The mobile phases flow rate was $1 \mathrm{~mL} \cdot \mathrm{min}^{-1}$ and consisted of $0.02 \mathrm{M}$ aqueous ammonium acetate adjusted to pH 5.0 with glacial acetic acid and acetonitrile (Zhao et al. 2006). The gradient was: $0 \rightarrow 15 \mathrm{~min}, 0 \% \rightarrow 2.3 \%$ solvent $\mathrm{B}$; $15 \rightarrow 45 \mathrm{~min}, 2.3 \% \rightarrow 37.9 \%$ solvent $\mathrm{B} ; 45 \rightarrow 50,37.9 \% \rightarrow 37.9 \%$ solvent $\mathrm{B} ; 50 \rightarrow 55 \mathrm{~min}, 37.9 \% \rightarrow 100 \%$ solvent $\mathrm{B} ; 55 \rightarrow 60 \mathrm{~min}$, $100 \% \rightarrow 100 \%$ solvent $\mathrm{B} ; 60 \rightarrow 65 \mathrm{~min}, 100 \% \rightarrow 0 \%$ solvent $\mathrm{B}$; $65 \rightarrow 70,0 \% \rightarrow 0 \%$ solvent. The sample injection volume was $20 \mu \mathrm{L}$. All analyses were carried out in triplicate and at laboratory temperature. The absorbance was monitored by DAD from wavelength 200 to $400 \mathrm{~nm}$. The amounts of AA in the samples were determined by a standard curve.

Preparation of calibration curve and quality control samples. - A standard sample of AA was dissolved in milliQ distilled water to a concentration of $1 \mathrm{mg} \cdot \mathrm{mL}^{-1}$. A six-point curve was obtained with injections of $20 \mu \mathrm{L}$ of $1,5,10,25$, $50,100 \mu \mathrm{g} . \mathrm{mL}^{-1}$ and the linear regression equation and correlation coefficients were calculated. AA in the samples was identified by comparison of retention times and coinjection with standards. Concentrations were calculated using peak areas of reference compound.

Quality control samples (10, 50, $100 \mu \mathrm{g} \cdot \mathrm{mL}^{-1}$ ) were independently and daily prepared in the extraction medium (acetonitrile/water).

Validation procedure.-The limit of detection was defined as the concentration, where the signal-to-noise value exceeded 3.0. Intra- and interassay precision also was evaluated by considering three concentrations $\left(10,50,100 \mu \mathrm{g} \cdot \mathrm{mL}^{-1}\right)$ prepared in triplicate and analyzed in the same day (intraday) and in different days (interday). The results are expressed as the coefficient of variation $(\mathrm{CV} \%)$ of the experimental values at each concentration.

Principal components analysis.-Principal components analysis (PCA) was performed with Matlab software 7.9.0 (Mathworks, Natick, Massachusetts) with PLS toolbox 5.5 (Eigenvector Research Inc., Wenatchee, Washington). It was applied as an unsupervised technique for reducing the number of variables (six variables corresponding to AA, BA, GA, PHD, PHS, PCD) to a smaller number of new derived variables (principal component or factors) that adequately summarize the original information. Moreover it allowed recognizing patterns in the data by plotting them in a multidimensional space, using the new derived variables as dimensions (factor scores). The aim of the PCA is to produce components suitable to be used as predictors or response variables in subsequent analysis (Rencher 1995).

\section{RESULTS}

Species identification and pH soil._A. phalloides specimens were identified with morphological features and appropriate keys and monographs including Courtecuisse (1999) and Courtecuisse and Duhem (2005). Morphological features that were important for species identification of A. phalloides included: cap convex or subplanar with a variance of olive-green to brown; gills free and white to cream; stipe white to pale yellow with fine radial striations; ring in upper part of the stipe, white to pale yellow, with radial striations; and volva globose and white.

The $\mathrm{pH}$ of all examined soil samples was strong to moderate acidic. The result showed that the means $\mathrm{pH}$ for Vinhais and Mogadouro were between $5.170 \pm$ 0.119 (strongly acidic) and $5.960 \pm 0.211$ (moderately acidic) respectively.

Extraction of toxins.-To ensure complete toxins extraction we performed the extraction at different time points $(1,2,3 \mathrm{~h})$. Because the $\alpha$-amanitin content was the same at different times, we performed a second extraction of the same mushroom sample and an additional rinse under the same conditions. The LC-MS analysis did not recover detectable amounts of residual toxins. The extraction method let us obtain complete toxins extraction, dispensing with the laborious and time-consuming steps. The process involves one solid/liquid extraction step followed by centrifugation. Another advantage of this method is that it requires only a small amount of mushroom sample $(0.5 \mathrm{~g})$.

Identification of $\alpha$-amanitin, $\beta$-amanitin, $\gamma$-amanitin, phalloidin, phallisin and phallacidin.-LC-DAD-MS analyses were performed to identify the main amatoxins and phallotoxins present in the mushroom tissues extract. The chemical structures of the main amatoxins and phallotoxins are illustrated (FIGS. 2, 3). The supposed identification of AA, BA, GA, PHD, PHS and PCD peaks detected under UV were based on their production spectra. The base peaks of the mass spectra were $m / z 919.20\left(\mathrm{C}_{39} \mathrm{H}_{54} \mathrm{~N}_{10} \mathrm{O}_{14} \mathrm{~S}\right)$ for AA, $m / z$ $920.13\left(\mathrm{C}_{39} \mathrm{H}_{53} \mathrm{~N}_{9} \mathrm{O}_{15} \mathrm{~S}\right)$ for $\mathrm{BA}, \mathrm{m} / z \quad 903.20$ $\left(\mathrm{C}_{39} \mathrm{H}_{54} \mathrm{~N}_{10} \mathrm{O}_{13} \mathrm{~S}\right)$ for $\mathrm{GA}, \mathrm{m} / \mathrm{z} 789.27 \quad\left(\mathrm{C}_{35} \mathrm{H}_{48}\right.$ $\left.\mathrm{N}_{8} \mathrm{O}_{11} \mathrm{~S}\right)$ for PHD, $m / z 805.27\left(\mathrm{C}_{35} \mathrm{H}_{48} \mathrm{~N}_{8} \mathrm{O}_{12} \mathrm{~S}\right)$ for PHS and $m / z \quad 847.20 \quad\left(\mathrm{C}_{37} \mathrm{H}_{50} \mathrm{~N}_{8} \mathrm{O}_{13} \mathrm{~S}\right)$ for PCD (TABLE I). The chromatographic ion peak $\left(\mathrm{M}+\mathrm{H}^{+}\right.$ at $m / z 903.20\left(\mathrm{C}_{39} \mathrm{H}_{54} \mathrm{~N}_{10} \mathrm{O}_{13} \mathrm{~S}\right)$ could correspond to either GA or amaninamide. Because amaninamide is 


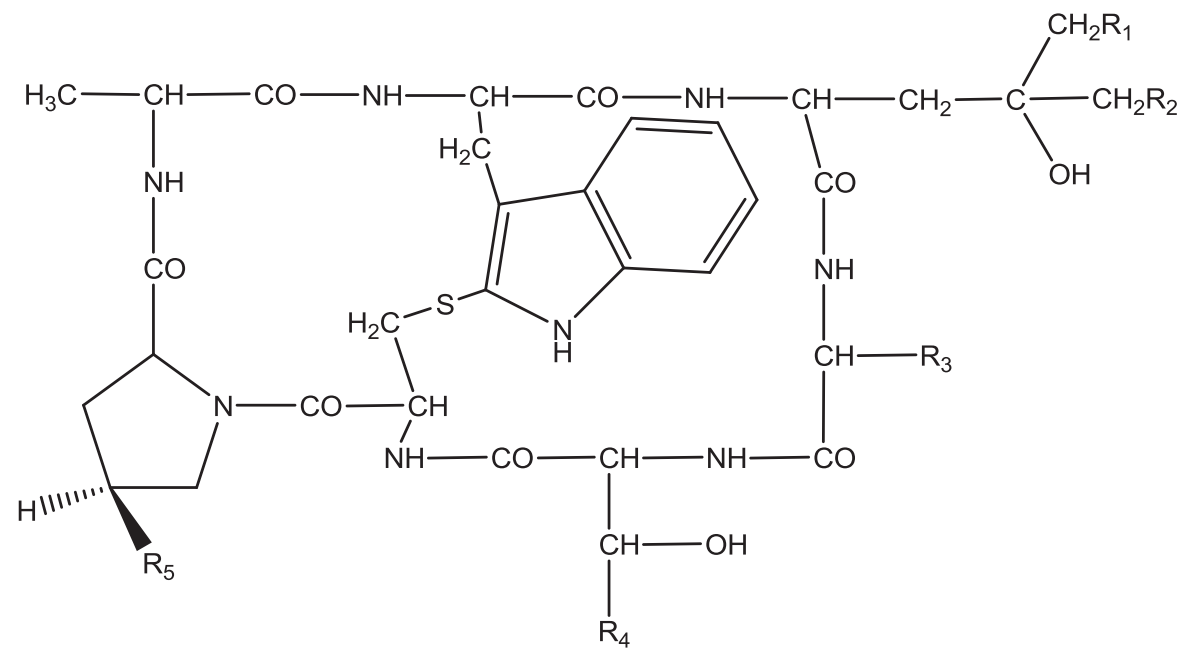

\begin{tabular}{llllll}
\hline & R1 & R2 & R3 & R4 & R5 \\
Phalloidin & $\mathrm{OH}$ & $\mathrm{H}$ & $\mathrm{CH}_{3}$ & $\mathrm{CH}_{3}$ & $\mathrm{OH}$ \\
Phalloin & $\mathrm{H}$ & $\mathrm{H}$ & $\mathrm{CH}_{3}$ & $\mathrm{CH}_{3}$ & $\mathrm{OH}$ \\
Prophallin & $\mathrm{H}$ & $\mathrm{H}$ & $\mathrm{CH}_{3}$ & $\mathrm{CH}_{3}$ & $\mathrm{H}$ \\
Phallisin & $\mathrm{OH}$ & $\mathrm{OH}$ & $\mathrm{CH}_{3}$ & $\mathrm{CH}_{3}$ & $\mathrm{OH}$ \\
Phallacin & $\mathrm{H}$ & $\mathrm{H}$ & $\mathrm{CH}\left(\mathrm{CH}_{3}\right)_{2}$ & $\mathrm{COOH}$ & $\mathrm{OH}$ \\
Phallacidin & $\mathrm{OH}$ & $\mathrm{H}$ & $\mathrm{CH}\left(\mathrm{CH}_{3}\right)_{2}$ & $\mathrm{COOH}$ & $\mathrm{OH}$ \\
Phallisacin & $\mathrm{OH}$ & $\mathrm{OH}$ & $\mathrm{CH}\left(\mathrm{CH}_{3}\right)_{2}$ & $\mathrm{COOH}$ & $\mathrm{OH}$ \\
& & & &
\end{tabular}

FIG. 3. Chemical structure of phallotoxins. The backbone structure is the same in all phallotoxins, and five variable groups determine the specific compound.

specific to Amanita virosa (Buku et al. 1980), we identified this chromatographic peak as being the GA. The protonated molecular peaks with a $\mathrm{NH}^{+}$ion $\left(\mathrm{M}+\mathrm{NH}_{4}\right)^{+}$peaks; m/z 935.67 for $\mathrm{AA}, \mathrm{m} / \mathrm{z} 936.67$ for BA, m/z 919.67 for GA, m/z 805.60 for PHD, m/z 821.47 for PHS and $\mathrm{m} / \mathrm{z} 863.47$ for PCD. A representative chromatogram recorded at $295 \mathrm{~nm}$ of A. phalloides cap extract is provided (FIG. 4).

Calibration and validation.-The representative regression equation for the calibration curve was $\mathrm{y}=$ $10266 \mathrm{x}+40831$ over $1.00-100.00 \mu \mathrm{g} \cdot \mathrm{mL}^{-1}$ with a coefficient of 0.991 . The lower limits of identification were $0.03 \mu \mathrm{g} . \mathrm{mL}^{-1}$. The intra- and interassay precision and accuracy determined with the blank mushroom extract that had been spiked with AA is indicated (TABLE II). The CV for the intra- and interassay was $0.65-2.03 \%$ for the three concentrations studied.

Contents and distribution of $\alpha$-amanitin in cap, stipe and volva. - The retention time for AA was 12.65 min. The concentrations in the samples are provided (TABLE III). The amount of AA in caps of A. phalloides 
TABLE I. Identified toxins in A. phalloides extract

\begin{tabular}{lclc}
\hline \hline $\begin{array}{c}\text { Compound } \\
\text { name }\end{array}$ & $\begin{array}{c}\text { Theoretical } \\
\text { monoisotopic }\end{array}$ & \multicolumn{1}{c}{$\begin{array}{c}\text { Elemental } \\
\text { composition }\end{array}$} & $\begin{array}{c}\text { Experimental } \\
{[\mathrm{M}+\mathrm{H}]^{+}}\end{array}$ \\
\hline$\alpha$-amanitin & 918.35 & $\mathrm{C}_{39} \mathrm{H}_{54} \mathrm{~N}_{10} \mathrm{O}_{14} \mathrm{~S}$ & 919.20 \\
$\beta$-amanitin & 919.34 & $\mathrm{C}_{39} \mathrm{H}_{53} \mathrm{~N}_{9} \mathrm{O}_{15} \mathrm{~S}$ & 920.13 \\
$\gamma$-amanitin & 902.36 & $\mathrm{C}_{39} \mathrm{H}_{54} \mathrm{~N}_{10} \mathrm{O}_{13} \mathrm{~S}$ & 903.20 \\
Phalloidin & 788.32 & $\mathrm{C}_{35} \mathrm{H}_{48} \mathrm{~N}_{8} \mathrm{O}_{11} \mathrm{~S}$ & 789.32 \\
Phallisin & 804.31 & $\mathrm{C}_{35} \mathrm{H}_{48} \mathrm{~N}_{8} \mathrm{O}_{12} \mathrm{~S}$ & 805.27 \\
Phallacidin & 846.32 & $\mathrm{C}_{37} \mathrm{H}_{50} \mathrm{~N}_{8} \mathrm{O}_{13} \mathrm{~S}$ & 847.20 \\
\hline
\end{tabular}

from Vinhais and Mogadouro, were $783.94 \pm 2.66$ $\mu \mathrm{g} \cdot \mathrm{g}^{-1}$ and $666.00 \pm 1.45 \mu \mathrm{g} \cdot \mathrm{g}^{-1}$ respectively (TABLE III). The stipes from Vinhais and Mogadouro contained $323.48 \pm 4.03 \mu \mathrm{g} \cdot \mathrm{g}^{-1}$ and $302.53 \pm 2.78$ $\mu \mathrm{g} \cdot \mathrm{g}^{-1}$ respectively (TABLE III). Finally the lowest concentrations were found in volva from Vinhais and Mogadouro, which contained $103.87 \pm 1.84 \mu \mathrm{g} . \mathrm{g}^{-1}$ and $73.16 \pm 1.66 \mu \mathrm{g} \cdot \mathrm{g}^{-1}$ respectively (TABLE III).

Amatoxin and phallotoxin composition in the different tissues.-Principal components analysis showed that $96.35 \%$ of the total variance of the data is explained using only three principal components. The representation of the two principal components factor scores obtained from the mushrooms harvest in two different geographical sites and the loadings of the variables are illustrated (FIG. 5). The first principal component accounting for $54.84 \%$ of total variance was strongly related to the tissue type. On the other hand the third principal component (13.58\% of total variance) was related to the collection site. The contrast between the two groups, the first group, projected in negative PC3 space composed by CV, SV and VV while the second group

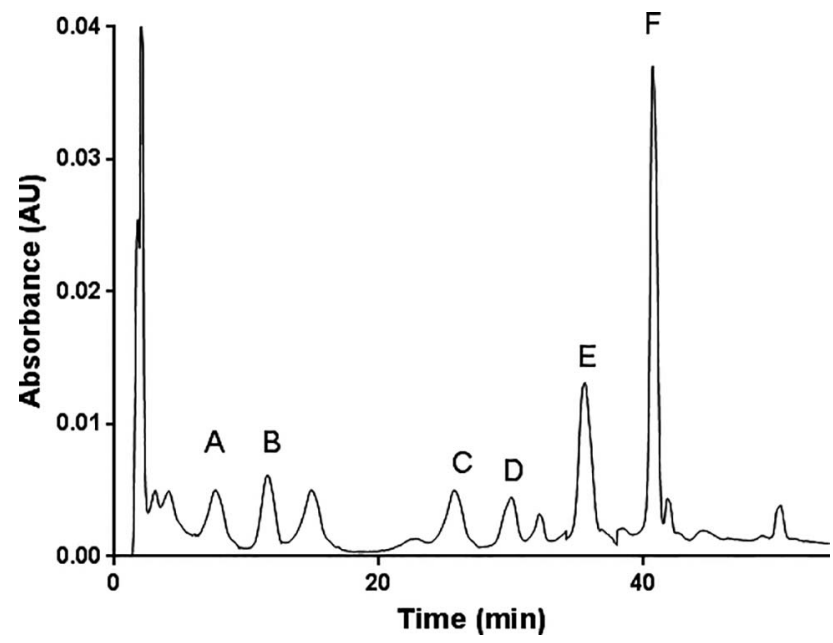

FIG. 4. Representative chromatogram recorded at 295 $\mathrm{nm}$ of $A$. phalloides cap from Vinhais. Peaks: $\mathrm{A}=\beta$ amanitin, $\mathrm{B}=\alpha$-amanitin, $\mathrm{C}=\gamma$-amanitin, $\mathrm{D}=$ phallacidin, $\mathrm{E}=$ phallisin; $\mathrm{F}=$ phalloidin.
TABLE II. Analytical accuracy and precision evaluated using standard spiked blank mushrooms

\begin{tabular}{lrr}
\hline $\begin{array}{c}\text { Concentration known } \\
\left(\mu \mathrm{g} \cdot \mathrm{mL}^{-1}\right)\end{array}$ & Concentration found & $\mathrm{CV}(\%)$ \\
\hline $\begin{array}{l}\text { Intra-assay }(\mathrm{n}=3) \\
1.00\end{array}$ & $0.90 \pm 0.03$ & \\
10.00 & $11.92 \pm 0.09$ & 0.76 \\
100.00 & $101.15 \pm 1.27$ & 1.26 \\
Interassay $(\mathrm{n}=3)$ & $0.87 \pm 0.02$ & 2.02 \\
1.00 & $11.90 \pm 0.24$ & 2.02 \\
10.00 & $106.58 \pm 0.84$ & 0.79 \\
100.00 & & \\
\hline
\end{tabular}

(projected in positive PC3 space), is represented by CM, SM and VM (FIG. 5A). The discrimination between these two groups is associated with the content in PHD and PHS, which is correlated with the third PCA axis (FIG. 5B). A differentiation along PC1 among different tissues, cap, stipe and volva is illustrated (FIG. 5A). Volva samples are projected on PC1 negative while caps are projected on PC1 positive and stipe between these two groups. The separation among these three groups is associated with the content in AA, BA and GA, which is very well correlated with the first PCA axis.

\section{DISCUSSION}

Because ingestion of $A$. phalloides mushrooms is responsible for several accidental or premeditated fatal intoxications, it is of great importance to have data concerning $A$. phalloides toxin total composition, its distribution in mushroom fruiting body tissues (cap, stipe, volva) and also its geographic preponderance. Few works are available in literature, and those available come from research in Poland, where several cases were reported (Lapinski and Prokopowicz 1998), France (Garrouste et al. 2009) and Czech Republic (Krenova et al. 2007). Every year several cases of mushroom intoxications are reported in Portugal. However no studies are available regarding toxins composition of $A$. phalloides growing in Portugal. Hence this work aimed at determining the quantitative differences in the toxins amount of the fruiting body tissues from A. phalloides mushrooms collected at different sites because at present no data is available on the quantity of toxins present in the Portuguese A. phalloides. These species exist throughout Portugal but with higher incidence in the northern part of the country. New cases of $A$. phalloides poisoning have been reported every year, however it is difficult to estimate the exact number of cases of amatoxin poisoning that occur due to underreporting procedures at hospital emergencies. 
TABLE III. Content of $\alpha$-amanitin in different tissues of A. phalloides

\begin{tabular}{lcc}
\hline \hline Tissue & Vinhais & Mogadouro \\
\hline Caps & $783.94 \pm 2.66^{\mathrm{a}}$ & $666.00 \pm 1.45^{\mathrm{a}}$ \\
Stipes & $323.48 \pm 4.03^{\mathrm{a}}$ & $302.53 \pm 2.78^{\mathrm{a}}$ \\
Volvas & $103.87 \pm 1.84^{\mathrm{a}}$ & $73.16 \pm 1.66^{\mathrm{a}}$ \\
\hline
\end{tabular}

${ }^{\mathrm{a}}$ Content ( $\mu \mathrm{g} \mathrm{g}^{-1}$ dry weight). Values are mean \pm standard deviation $(\mathrm{n}=3)$.

As described before, this species contains two groups of toxins, amatoxins and phallotoxins. The lessharmful phallotoxins are poorly absorbed through the intestine, although they may contribute to the early gastrointestinal symptoms (Karimi and Razavi 2014). The group of amatoxins is mainly composed of AA. Our results showed that the content of this toxin and its distribution in tissues of $A$. phalloides varied significantly. The highest amounts were found in the cap and stipe and the lowest amount in the volva of the A. phalloides. The cap AA content was twice that in the stipe and four times higher than in the volva. The content and distribution of toxins in different tissues of A. phalloides also were investigated by Enjalbert et al. (1993). Their data revealed significant variations in the amounts of toxins present in the various tissues of A. phalloides, which is consistent with our findings, although they found higher amounts. This apparent discrepancy may be explained by environmental factors and genetic differences. The amount of toxin present also might be dependent on the age of the collected species, which also might be reflected in the variation of our values. The collected $A$. phalloides specimens were mature, which explains the lower values that are consistent with results presented by $\mathrm{Hu}$ et al. (2012).

Concerning the environmental conditions of the collection area (temperature, microclimate, soil, $\mathrm{pH}$ ), it seems they play a determinant role in amatoxin and phallotoxin profile. Accordingly Enjalbert et al. (1996) reported that the locality significantly influences toxin composition of the fruiting body tissues, a finding that is also corroborated in the present study. In fact the geographic, topographic, climatic and soil $\mathrm{pH}$ differences between the two areas analyzed seem to have an impact on toxin profile. Our findings pointed out that the site-specific environmental conditions have a greater influence on phallotoxin than on amatoxin composition, which is in agreement with Enjalbert et al. (1996). The greatest variations in the toxin concentration were recorded for PHD and PHS in the stipes from Vinhais and Mogadouro. The highest PHD concentration was found in the stipe from Mogadouro. On the other hand the highest PHS concentration was found in the stipe from Vinhais. A. phalloides belongs to a category called ectomycorrhizal-symbiotic fungi. These fungi are known to have an intimate symbiotic relationship with their host plants. In this context an ectomycorrhizal fungus gains carbon supply and other essential organic substances from the tree and in return the plant benefits by receiving water and nutrients. Therefore the close ties between ectomycorrhizal fungi and their plant hosts would lead us to expect greater host influence on chemical composition of ectomycorrhizal mushrooms species. The A. phalloides specimens from Vinhais were in a symbiotic association with chestnut tree, and specimens from

B

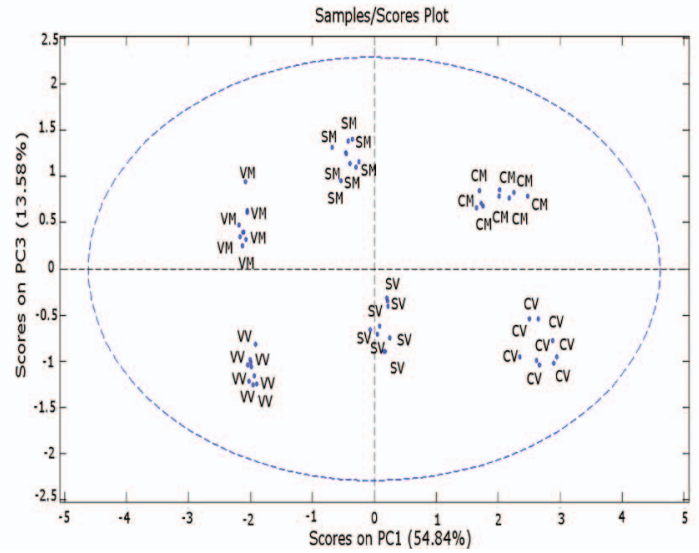

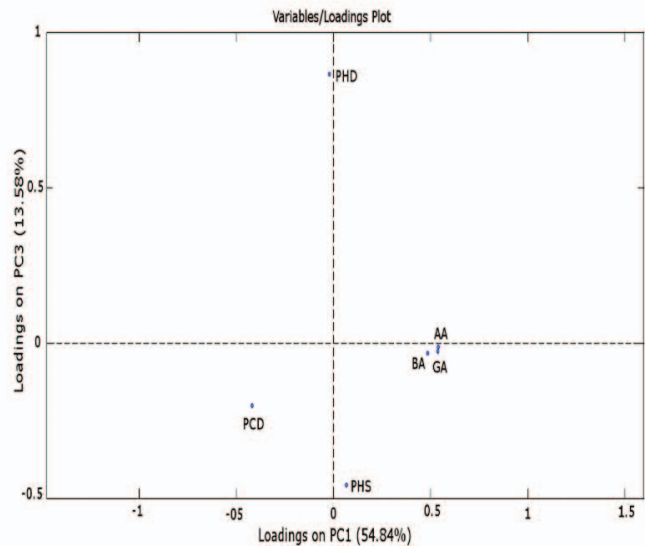

FIG. 5. A. Principal components scores plots of the data from the mushrooms HPLC-DAD spectra. B. Principal components analysis loading plots of the variables $\alpha$-amanitin (AA), $\beta$-amanitin (BA), $\gamma$-amanitin (GA), phalloidin (PHD), phallacidin (PCD) and phallisin (PHS). Key: cap from Vinhais (CV), stipe from Vinhais (SV), volva from Vinhais (VV), cap from Mogadouro (CM), stipe from Mogadouro (SM), Volva from Mogadouro (VM). 


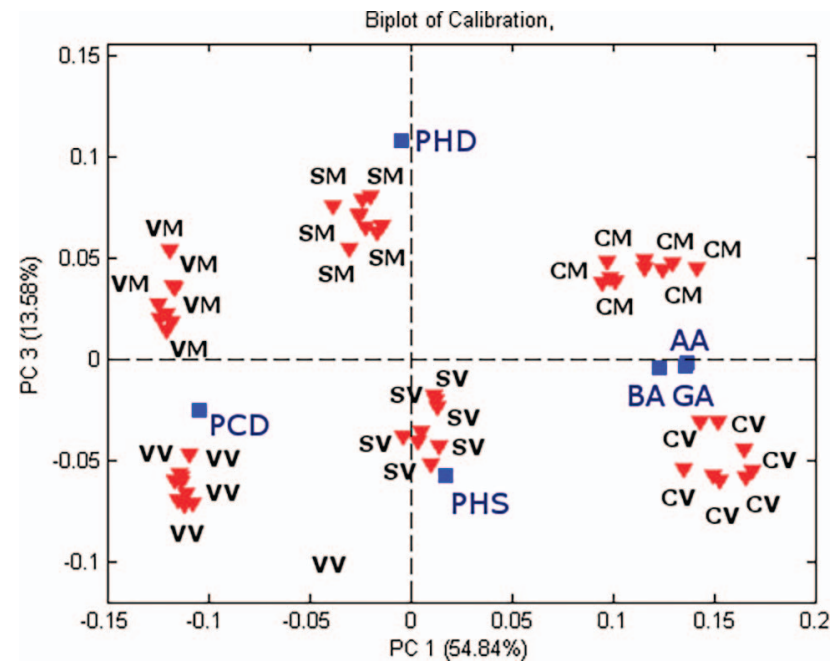

FIG. 6. Principal components scores and loading plots.

Mogadouro were in a symbiotic association with oak tree. Thus we strongly think that host tree and the surrounding flora involved in the symbiotic relationship could influence the chemical composition of mushrooms.

The multivariate techniques of data analysis was used to obtain more information on the variables that mainly influence the sample similarities and/or differences. The same technique has been applied by our group to discover molecules that can be used to assist in identifying mushroom species (Carvalho et al. 2014); six molecules can be species- or genusspecific were successfully identified. In the present study we are able to discriminate the different tissues that composed fruiting body mushroom based on toxin composition. Therefore the cap tends to contain more amatoxins (AA, BA, GA) than stipe and volva (FIG. 6). In contrast volva exhibited the lowest concentration of amatoxins. On the other hand volva contains more PCD than caps and stipes (FIG. 6).

Taken together these results based on statistical evaluation of HPLC-DAD data revealed that amatoxins and phallotoxins are not equally distributed in the fruiting body tissues and vary from one area to another. Furthermore findings from this study support the hypothesis that environmental conditions play a significant role in the content of toxins.

\section{ACKNOWLEDGMENTS}

Authors are grateful to Dr Zélia dos Santos Azevedo, Faculty of Sciences, University of Porto, who loaned LC/DAD-ESI/ MS and for all technical assistance. The authors also are grateful for the help of the Foundation for the Science and Technology (FCT, Portugal) for financial support and also thank FCT for doctoral grant SFRH/BD/74979/2010.

\section{LITERATURE CITED}

Agroconcultores Coba. 1991. Carta darta dos Solos. Carta do Uso Actual da Terra e Carta de Aptidão da Terra do Nordeste de Portugal. Vila Real: UTAD/PDRITM. p 153-163.

Barceloux DG. 2008. Medical toxicology of natural substances: foods, fungi, medicinal herbs, plants and venomous Animals. Hoboken, New Jersey: John Wiley \& Sons Inc. 272 p.

Bonnet MS, Basson PW. 2002. The toxicology of Amanita phalloides. Homeopathy 91:249-54, doi:10.1054/homp. 2002.0056

Buku A, Wieland T, Bodenmuller H, Faulstich H. 1980. Amaninamide, a new toxin of Amanita virosa mushrooms. Experientia 36:33-34, doi:10.1007/BF02003953

Carvalho LM, Carvalho F, de Lourdes Bastos M, Baptista P, Moreira N, Monforte AR, da Silva Ferreira AC, de Pinho PG. 2014. Non-targeted and targeted analysis of wild toxic and edible mushrooms using gas chromatography-ion trap mass spectrometry. Talanta 118:292303, doi:10.1016/j.talanta.2013.09.038

Courtecuisse R. 1999. Mushrooms of Britain and Europe. London: HarperCollins. 281 p.

— Ibérica, Europa y Norte de África. Barcelona, Spain: Ediciones Omega. 301 p.

Dias LG, Pereira AP, Estevinho LM. 2012. Comparative study of different Portuguese samples of propolis: pollinic, sensorial, physicochemical, microbiological characterization and antibacterial activity. Food Chem Toxicol 50:4246-53, doi:10.1016/j.fct.2012.08.056

Enjalbert F, Cassanas G, Guinchard G, Chaumont J. 1996. Toxin composition of Amanita phalloides tissues in relation to the collection site. Mycologia 88:909-921, doi: $10.2307 / 3761053$

, Gallion C, Jehl F, Monteil H, Faulstich H. 1992. Simultaneous assay for amatoxins and phallotoxins in Amanita phalloides Fr. by high-performance liquid chromatography. J Chromatogr 598:227-236, doi:10.1016/0021-9673(92)85052-U

- - - - - — 1993. Toxin content, phallotoxin and amatoxin composition of Amanita phalloides tissues. Toxicon 31:803-807, doi:10.1016/ 0041-0101(93)90386-W

— — - Salhi SL, Guinchard C, Chaumont JP. 1999. Distribution of the amatoxins and phallotoxins in Amanita phalloides. Influence of the tissues and the collection site. CR Acad Sci III 322:855-62.

— N, Cabot C. 2002. Treatment of amatoxin poisoning: 20-year retrospective analysis. J Clin Toxicol 40:715-57, doi:10.1081/CLT-120014646

Evelpidou N, Figueiredo T, Mauro F, Tecim V, Vassilopoulos A. 2010. Natural heritage from east to west: case studies from six EU countries. Berlin: Springer Verlag. $122 \mathrm{p}$.

FAO/UNESCO. 1987. Soil map of the world. Revised legend, amended 4th draft. Rome: United Nations Food and Agriculture Organization. 
Garcia J, Carvalho AT, Dourado DF, Baptista P, de Lourdes Bastos M, Carvalho F. 2014. New in silico insights into the inhibition of RNAP II by alpha-amanitin and the protective effect mediated by effective antidotes. J Mol Graph Model 51:120-127, doi:10.1016/j.jmgm.2014.05.002

Garrouste C, Hemery M, Boudat AM, Kamar N. 2009. Amanita phalloides poisoning-induced end-stage renal failure. Clin Nephrol 71:571-574, doi:10.5414/CNP71571

$\mathrm{Hu}$ J, Zhang P, Zeng J, Chen Z. 2012. Determination of amatoxins in different tissues and development stages of Amanita exitialis. J Sci Food Agric 92:2664-2667.

Jansson D, Fredriksson SA, Herrmann A, Nilsson C. 2012. A concept study on identification and attribution profiling of chemical threat agents using liquid chromatography-mass spectrometry applied to Amanita toxins in food. Forensic Sci Int 221:44-49.

Karimi G, Razavi B. 2014. Poisonous mushrooms. In: Gopalakrishnakone P, Faiz SMA, Gnanathasan CA, Habib AG, Fernando R, Yang C-C, eds. Clin Toxinol. the Netherlands: Springer. p 1-18.

Karlson-Stiber C, Persson H. 2003. Cytotoxic fungi-an overview. Toxicon 42:339-49, doi:10.1016/S0041-0101 (03) 00238-1

Kaya E, Karahan S, Byram R, Yaykasli KO, Colakoglu S, Saritas A. 2013. Amatoxin and phallotoxin concentration in Amanita phalloides spores and tissues. Toxicol Ind Health 1-6.
Krenova M, Pelclova D, Navratil T. 2007. Survey of Amanita phalloides poisoning: clinical findings and follow-up evaluation. Hum Exp Toxicol 26:955-61, doi:10.1177/ 0960327107085832

Lapinski TW, Prokopowicz D. 1998. Epidemiological factors of mushroom poisoning in the northeast of Poland. Przegl Epidemiol 52:463-67.

Mas A. 2005. Mushrooms, amatoxins and the liver. J Hepatol 42:166-169, doi:10.1016/j.jhep.2004.12.003

Rencher A. 1995. Methods of multivariate analysis. New York,: John Wiley \& Sons Inc. 380 p.

Serné EH, Toorians AWFT, Gietema JA, Bronsveld W, Haagsma EB, Mulder POM. 1996. Amanita phalloides, a potentially lethal mushroom: its clinical presentation and therapeutic options. Neth J Med 49:19-23.

van Hoek B, de Boer J, Boudjema K, Williams R, Corsmit O, Terpstra OT. 1999. Auxiliary versus orthotopic liver transplantation for acute liver failure. EURALT study group. European auxiliary liver transplant registry. J Hepatol 30:699-705.

Vetter J. 1998. Toxins of Amanita phalloides. Toxicon 36: 13-24, doi:10.1016/S0041-0101 (97)00074-3

Zhao J, Cao M, Zhang J, Sun Q, Chen Q, Yang ZR. 2006. Pathological effects of the mushroom toxin alphaamanitin on BALB/c mice. Peptides 27:3047-52, doi:10.1016/j.peptides.2006.08.015 